\title{
Evaluation the Relationship Between Serum and Salivary Levels of 25(OH)Vit.D with Type II Diabetes in Newly Diagnosed Diabetics
}

\author{
Hamidreza Abdolsamadi ${ }^{1}$, Mohammad Vahedi ${ }^{1}$, Shiva Borzouei ${ }^{2}$, Alireza Soltanian ${ }^{3}$, Ali Hosseini ${ }^{4}$ \& \\ Meghdad Zakavati Avval ${ }^{4}$ \\ ${ }^{1}$ Dental Research Center, Department of Oral Medicine, Dental School, Hamadan University of Medical Sciences, \\ Hamadan, Iran \\ ${ }^{2}$ Department of Internal Medicine-Endocrinology, School of Medicine, Hamadan University of Medical Sciences \\ \& Health Services, Hamadan, Iran \\ ${ }^{3}$ Department of Biostatistics \& Epidemiology, school of public Health and modeling of non-communicable \\ diseases research center, Hamadan University of Medical Sciences, Hamadan, Iran \\ ${ }^{4}$ Department of Oral \& Maxillofacial Medicine, Dental School, Hamadan University of Medical Sciences, \\ Hamadan, Iran \\ Correspondence: Ali Hosseini, Postgraduate of Oral Medicine, Department of Oral \& Maxillofacial Medicine, \\ Dental School, Hamadan University of Medical Sciences, Hamadan, Iran. E-mail: dr.ali77h@gmail.com
}

Received: July 9, 2017

Accepted: July 21, 2018

Online Published: July 24, 2018

doi:10.5539/jmbr.v8n1p108

URL: https://doi.org/10.5539/jmbr.v8n1p108

\begin{abstract}
Introduction: The International Diabetes Federation (IDF) Announces 415 million people around the world are suffering from diabetes. There is a high proportion of UDM (undiagnosed diabetes) at the level of the world and particularly in developing countries. The number of people with UDM in Iran in 2015 are 2197.96 per 1000. Vitamin $\mathrm{D}_{3}$ deficiency is associated with increased risk of type 2 diabetes and for a long time, been recognized as a risk factor for glucose intolerance. Salivary composition, as the mirror of oral health, its use as a diagnostic tool is increasing and diabetes is also can be effective on the flow rate of saliva and its compounds. Analysis of saliva can be used as part of the evaluation of endocrine function.
\end{abstract}

Material and Methods: In this case-control study in 2016 in Hamadan, we selected 57 newly diagnosed patients with type 2 diabetes mellitus with mean aged 47.73 years and 57 healthy controls with mean aged 45.36 years. By using Spitting method, $5 \mathrm{ml}$ of completely unstimulated saliva samples were collected from diabetic patients and control subjects. The serum and saliva 25(OH)Vit.Dconcentrations were measured by ELISA. The results are analyzed by SPSS 16.

Results: Significant difference was found in serum concentrations between the two groups $(p<0.001)$. But in unstimulated whole salivary 1,25(OH) 2D3 concentrations between the two groups, difference was not significant and the relationship, was reversed. There was a significant correlation $(\mathrm{P}=0.013)$ between serum and saliva 1 , $25(\mathrm{OH}) 2 \mathrm{D} 3$ concentrations in the control group. In other words, the correlation was approximately 0.33 . Correlation between serum and saliva $1,25(\mathrm{OH}) 2 \mathrm{D} 3$ concentrations in case group was not significant. Serum levels of $1,25(\mathrm{OH}) 2 \mathrm{D} 3$ in $21.1 \%$ of control group, showed the inadequate level (Vit. $\mathrm{D}_{3}=20-29 \mathrm{ng} / \mathrm{ml}$ ) and in the case group, showed the critical situation and overall $91.2 \%$ of the newly diagnosed diabetics, suffered from lack of vitamin $\mathrm{D}_{3}$. According to the salivary levels of $1,25(\mathrm{OH}) 2 \mathrm{D}_{3}$, in general, a total of $58 \%$ of the case group, have deficiency of vitamin $\mathrm{D}_{3}$.

Conclusion: The results was confirmed vitamin $\mathrm{D}_{3}$ deficiency in participating in the study population (both case and control). The findings showed that there is lower concentration of $1,25(\mathrm{OH}) 2 \mathrm{D}_{3}$ in serum and after that in saliva in diabetic patients that newly diagnosed. Saliva would play a helpful diagnostic role in the early detection, the monitoring and progression of diabetes, but still serum is the better method for detecting vit. $\mathrm{D}_{3}$ levels and more research needs to be done on saliva for detecting Vit. $D_{3}$ concentrations.

Keywords: Newly diagnosed diabetes, vitamin $\mathrm{D}_{3}$ deficiency, saliva and serum 


\section{Introduction}

The prevalence of diabetes in the world, is rapidly increasing. 415 million people (one out of every 11 people adult) have diabetes. There is the number of people with diabetes in 2015, 215.2 million in men and 199.5 million in women. that in 2040, increased to 328.4 million in men and 313.3 million in women and one of the two adults with diabetes is undiagnosed (Atlas, 2015b). There is a high proportion of undiagnosed diabetes (174/8 million) especially in developing countries in the world (Rahimi et al., 2016). By 2015, totaling 6.4 million (43.8\%) have diabetes in Iran ("International Diabetes Federation - Search," 2017). Also in Iran, 7.7\% of adults between the ages of 64-25 years ( 2 million) have diabetes, that half of them are undiagnosed (Gu et al., 2003). According to the International Diabetes Federation estimation in 2015, the number of people with undiagnosed diabetes (20-79 years) in Iran is 2197.96 in 1000 (Atlas, 2015b). In a study of over 2.7 million adults in Iran, about half of the cases were newly diagnosed diabetic (Esteghamati et al., 2009). In recent decades a large number of non-skeletal diseases with vitamin D3 deficiency, including type 2 diabetes have been reported (Zittermann, 2006). Vitamin D3 plays a major role in maintaining normal glucose homeostasis and its deficiency is associated with increased risk of type 2 diabetes (Danescu, Levy, \& Levy, 2009; Pittas, Lau, Hu, \& Dawson-Hughes, 2007).Vitamin $\mathrm{D}_{3}$ deficiency, caused by the loss or partial resistance to it, is known as the risk factor for glucose intolerance in a long time (Boucher, 1998; Zittermann et al., 2003). Daniel mouse (2015) reported that 25 (OH) D deficiency could be implicated in the pathogenesis of type 2 diabetes and the exact mechanism still is unclear. High Body mass index (BMI) and less physical activity (Known risk factors for type 2 diabetes) is associated with deficiency of $25(\mathrm{OH})$ D And $33 \%$ of people with diabetes, newly diagnosed cases of diabetes (Mauss, Jarczok, Hoffmann, Thomas, \& Fischer, 2015). Lesser amounts of vitamin D3 in newly diagnosed diabetic patients with type 2 diabetes in a study in New Zealand, was observed (Scragg et al., 1995). Lack of vitamin $\mathrm{D}_{3}$ depending on the level of deficiency, may affect glucose homeostasis, insulin secretion and insulin resistance (J Boucher, 2011). The average level of vitamin D3 in patients with type 2 diabetes generally is lower than healthy individuals (Rahimi et al., 2016). Administration of vitamin $\mathrm{D}_{3}$ supplementation (once a week) for 8 weeks at dose $50000 \mathrm{IU}$ in patients with type 2 diabetes, Can improve the inadequate levels of vitamin D3 to be effective, improve blood sugar control index and increase insulin sensitivity (Baziar et al., 2014; talaei, mohamadi kelishadi, \& adgi, 2011). There are 1 billion people with (3087\%) deficiency or insufficiency of vitamin D3 around the World (Makariou, Liberopoulos, Elisaf, \& Challa, 2011; Mauss et al., 2015). The maximum amount of vitamin $\mathrm{D}_{3}$ deficiency is from the Middle East. The cause of the lack of $25(\mathrm{OH}) \mathrm{D}$ levels Less than $15 \mathrm{ng} / \mathrm{ml}$ in the Middle East $(72.8 \%)$ that amount was much lower $(83.9 \%$ in women and $48.5 \%$ in men) is related to the culture and religious activities that lead to less sun exposure in women compared to men. Nursing home residents (60\%) and hospitalized patients $(57 \%)$ in the United States of America had vitamin D3 deficiency (Tangpricha \& Khazai, 2010). The trend of the prevalence of vitamin D3 deficiencies in Iran is on the rise (Saeidinia et al., 2013). In the urban population living in Tehran, serum vitamin $\mathrm{D}_{3}$ plays a significant role in cardiovascular disease (Hosseinpanah et al., 2011). The latest criteria for assessing the extent of the deficiency of vitamin D3 Is considered severe deficiency $(<10 \mathrm{ng} / \mathrm{ml})$, Moderate deficiency $(10-19.9 \mathrm{ng} / \mathrm{ml})$, Insufficiency $(20-29.9 \mathrm{ng} / \mathrm{ml})$ and normal $(\geq 30 \mathrm{ng} / \mathrm{ml})$.Vitamin D3 deficiency screening is not recommended for healthy adults, while, at present, according to the Endocrine Society screening guidelines can be used for people at risk for type 2 diabetes (Mauss et al., 2015). Salivary fluid, such as serum or plasma as unique and complex at the same time the body is considered (Krishna, Ashalatha, Baghirath, Kanth, \& Malathi, 2010).The use of saliva as a mirror of oral health as a diagnostic method is on the rise. Salivary flow rate and composition in patients with type 2 diabetes, affected by diabetes, salivary flow rate and composition is affected by diabetes in patients with type 2 diabetes and analysis of saliva can applied Endocrinology as part of the performance evaluation and Recently, whole saliva and related compounds is considered, as a new tool in the hormone testing (Carda, Mosquera-Lloreda, Salom, Gomez de Ferraris, \& Peydró, 2006; Greabu et al., 2009; Higashi, Hijikuro, Yamagata, \& Ogawa, 2013). Vitamin $\mathrm{D}_{3}$ is found in saliva and the average is $434 \mathrm{pg} / \mathrm{ml}$, the values fluctuate throughout the day and the quantity of vitamin $\mathrm{D}_{3}$ may be related to food and ethnic origin (Fairney \& Saphier, 1987). Due to the high incidence of deficiency of vitamin D3 in Iran and the Middle East region with the highest prevalence of deficiencies in the world, As well as the prevalence of 5.4 million people with DM in Iran (Atlas, 2015a; Tangpricha \& Khazai, 2010), Close relationship between deficiency of vitamin $\mathrm{D}_{3}$ with diabetes, and the importance of assessing levels of vitamin $\mathrm{D}_{3}$ in this patients to prevent and reduce complications associated with vitamin $\mathrm{D}_{3}$ deficiency, this study was designed. Aimed to evaluate levels of salivary and serum $25(\mathrm{OH}) \mathrm{D}$ in patients with newly diagnosed type 2 diabetes and its relation to diabetes, this study was designed in Hamedan regarding included in the common areas row of the deficiency of vitamin D3 in Iran. Also, other objectives of this review was compare the salivary levels of vitamin $\mathrm{D}_{3}$ with serum levels of it, to verify the measurement accuracy through saliva, and replace this method by measuring the serum. Having in mind the benefits with the measurement of 1, $25(\mathrm{OH}) 2 \mathrm{D} 3$ in saliva, Including the speed and ease of doing it, Being a low-cost, As well as being a non- 
invasive and non-stress method, to evaluate the levels of vitamin D3 with a rapid, cheap and without stress and anxiety method for diabetic patient, and in order to find the relationship between the level of vitamin deficiency and diabetes-related complications, in each patient, this study was designed.

\section{Materials and Methods}

In this case control study, 57 patients with newly diagnosed type 2 diabetes (in accordance with the standards of the Diabetes Association of America "ADA") (Association, 2014) were selected by the physician endocrinologist with check FBS and $\mathrm{HbA1C}$ (Table 2). Immediately after the confirmation of the diagnosis and before receiving any treatment of anti-diabetic and after measurement of height and weight and calculate BMI (body mass index) using the formula $\mathrm{Kg} / \mathrm{m}^{2}$ (weight/height ${ }^{2}$ ), a sampling of the saliva of these people was conducted. Sampling of 57 persons healthy saliva of healthy patients as partners during the past three months have no history of any systemic diseases such as diabetes or taking medications, calcium and vitamin $\mathrm{D}_{3}$ supplements and were smoking. Criteria for inclusion include the confirmation of the diagnosis of type 2 diabetes cases by specialist physicians, lack of receiving treatment for disease control before proceeding to sampling, the desire to collaborate in research and the completion of the questionnaire. Exclusion criteria included lack of desire to participate in the study, have any systemic diseases including liver disease, chronic kidney disease or any creatinine levels outside the normal range of $0.6-2.1 \mathrm{mg} / \mathrm{dl}$, More or less than normal amount of calcium $(9-11 \mathrm{mg} / \mathrm{dl})$, Malignancy, pregnancy or breastfeeding, taking any medication like calcitonin, bisphosphonates, steroids, supplements of calcium and vitamin D3 as well as alcohol and cigarettes in the last 3 months And BMI greater than $40 \mathrm{Kg} / \mathrm{m}^{2}$ (Obesity). To check the status BMI and obesity, weight was measured using a special scale. To measure the height, the tape was used standing, one without shoes and with a touch of heel and thigh and scapula with the wall. Collect saliva samples was performed using Spitting (Greabu et al., 2009). In addition, to collect samples of unstimulated, so ensure that people refrain from eating and drinking or any oral stimulation (e.g., chewing gum) for 90 minutes prior to sample collection for 90 minutes prior to sample collection and it typically every 60 seconds for 5-15 minutes to do. To minimize variations in the sample, sampling at a specified time limit and was conducted in the spring and summer. Put the sample inside the container contains ice, were transferred to the laboratory immediately and in order to isolate debris and squamous cells, the samples were centrifuged for $10 \mathrm{~min}$ at $4{ }^{\circ} \mathrm{C}$ (at $2500 \mathrm{~g}$ speed) and then to collect all samples for testing, at the temperature of $-20^{\circ} \mathrm{C}$, were frozen. The salivary and serum samples were measured with Human vitamin D ELISA Kit, manufacturing company "Bioassay Laboratory technology" China. The serial number of the Cat. No: E1537Hu. The kit uses a double-antibody sandwich enzymelinked immunosorbent assay (ELISA) to assay the level of Human Vitamin $\mathrm{D}_{3}$ in samples.

Table 1. Gender distribution

\begin{tabular}{|c|c|c|c|c|c|}
\hline \multirow{2}{*}{\multicolumn{2}{|c|}{ gender distribution }} & \multicolumn{2}{|c|}{ groups } & \multirow{2}{*}{ Total } & \multirow{2}{*}{ Chi-Square Tests } \\
\hline & & Control & Case & & \\
\hline Female & Count & $\begin{array}{c}39 \\
68.4 \%\end{array}$ & $\begin{array}{c}34 \\
59.6 \%\end{array}$ & $\begin{array}{c}73 \\
64.0 \%\end{array}$ & $\begin{array}{c}\mathrm{X} 2=0.952 \\
\mathrm{df}=1\end{array}$ \\
\hline Male & Count & $\begin{array}{c}18 \\
31.6 \%\end{array}$ & $\begin{array}{c}23 \\
40.4 \%\end{array}$ & $\begin{array}{c}41 \\
36.0 \%\end{array}$ & $\begin{array}{c}\mathrm{df}=1 \\
\mathrm{P}=0.329\end{array}$ \\
\hline
\end{tabular}

Table 2. Comparison of blood parameters in both case $(n=57)$ and control groups

\begin{tabular}{cccc}
\hline & groups & Mean & Std. Deviation \\
\hline Age & control & 45.3684 & 9.50870 \\
& case & 47.7368 & 12.98285 \\
Height & control & 1.6568 & .06185 \\
& case & 1.6661 & .07161 \\
Weight & control & 71.7018 & 8.43878 \\
& case & 75.0175 & 13.94439 \\
BMI & control & 26.0960 & 2.60719 \\
& case & 26.9640 & 4.49713 \\
FBS & control & 91.3684 & 6.68322 \\
& case & 217.252 & 115.48133 \\
HbAlc & control & 5.6167 & .82075 \\
& case & .7229 & 2.35300 \\
serum_Ca & control & 9.4404 & .66409 \\
& case & 9.1789 & .47799 \\
Serum_Creatinin & control & .7561 & .22758 \\
& case & .8333 & .22939 \\
\hline
\end{tabular}


Table 3. Relationship between the amount of serum and salivary vitamin D3 with diabetes

\begin{tabular}{cccc}
\hline & groups & Mean \pm sd & t-test \\
\hline serum vitamin D3 & control & $37.6351 \pm 8.61028$ & \\
& case & $15.3105 \pm 7.46902$ & $\mathrm{~T}=14.787$ \\
salivary vitamin D3 & control & $20.8807 \pm 3.95296$ & $\mathrm{df}=109.809$ \\
& case & $27.9053 \pm 10.91476$ & $\mathrm{P}<.000$ \\
\hline
\end{tabular}

Table 4. compare the values of serum vitamin D3 in the case and control groups

\begin{tabular}{cccc}
\hline $\begin{array}{c}\text { serum vitamin D3 } \\
\text { (ng/d) }\end{array}$ & & $\begin{array}{c}\text { Control } \\
\mathrm{n}(\%)\end{array}$ & case \\
& $\leq 10$ & 0 & $1 \%)$ \\
\hline Severe Deficiency & & $.0 \%$ & $31.6 \%$ \\
Moderate deficiency & $11-19$ & 0 & 26 \\
& & $.0 \%$ & $45.6 \%$ \\
Insufficiency & $20-29$ & 12 & 8 \\
& & $21.1 \%$ & $14.0 \%$ \\
Normal & $\geq 30$ & 45 & 5 \\
& & $78.9 \%$ & $8.8 \%$ \\
\hline
\end{tabular}

Table 5. compare the values of salivary vitamin D3 in the case and control groups

\begin{tabular}{cccc}
\hline $\begin{array}{c}\text { salivary vitamin D3 } \\
\text { (ng/d) }\end{array}$ & & $\begin{array}{c}\text { Control } \\
\mathrm{n}(\%)\end{array}$ & case \\
& $\leq 10$ & 0 & $4 \%)$ \\
\hline Severe Deficiency & & $.0 \%$ & $7.0 \%$ \\
Moderate deficiency & $11-19$ & 29 & 8 \\
& & $50.9 \%$ & $14.0 \%$ \\
Insufficiency & $20-29$ & 25 & 21 \\
& & $43.9 \%$ & $36.8 \%$ \\
Normal & $\geq 30$ & 3 & 24 \\
& & $5.3 \%$ & $42.1 \%$ \\
\hline
\end{tabular}

\section{Findings}

57 patients with newly diagnosed type 2 diabetes, with an average age of 47.73 years ( 34 women and 23 men) And 57 healthy volunteers ( 39 females and 18 males) with an average age of 45.36 years, participated in the study (Table 1\&2). The average serum levels of vitamin $\mathrm{D}_{3}$ in the control group, $37.6 \mathrm{ng} / \mathrm{ml}$ and in the case group was $15.3 \mathrm{ng} / \mathrm{ml}$. The average level of saliva was 20.8 in the control group, and in the case group was $27.9 \mathrm{ng} / \mathrm{ml}$. In comparison, the average serum vitamin $\mathrm{D}_{3}$ in healthy people with diabetics, the difference was significant $(\mathrm{P}<0.001)$. This communication about average vitamin $\mathrm{D}_{3}$ in saliva, was reversed. There is a direct and significant correlation between serum and salivary vitamin $\mathrm{D}_{3}$ in control group $(\mathrm{p}=0.013)$ and the correlation between serum and salivary vitamin $\mathrm{D}_{3}$ is about 0.33 that in case group, this correlation was reversed. (Table 3) In Evaluation of Serum Levels of vitamin $\mathrm{D}_{3}$ (Table 4), the deficiency was observed in both groups that in $21.1 \%$ of cases in control group, was insufficient $(20-29 \mathrm{ng} / \mathrm{ml})$. There were no severe deficiency of vitamin $\mathrm{D}_{3}(<10 \mathrm{ng} / \mathrm{ml})$ as well as moderate deficiency $(10-19 \mathrm{ng} / \mathrm{ml})$ and in $78.9 \%$ based on more than $30 \mathrm{ng} / \mathrm{ml}$ and was normal. But the situation in the case Group (newly diagnosed diabetic patients) was more critical. $31.6 \%$ have severe deficiency of vitamin $\mathrm{D}_{3}(<10 \mathrm{ng} / \mathrm{ml})$ and $45.6 \%$ have moderate deficiency $(10-19 \mathrm{ng} / \mathrm{ml})$. There were inadequacy of vitamin $\mathrm{D}_{3}(20-$ $29 \mathrm{ng} / \mathrm{ml})$ in $14 \%$ and normal levels $(>30 \mathrm{ng} / \mathrm{ml})$ in $8.8 \%$ of the cases. Overall $91.2 \%$ of newly diagnosed diabetics, suffered from a lack of vitamin $\mathrm{D}_{3}$. The results generally confirms the prevalence of deficiencies of vitamin $\mathrm{D}_{3}$ in the statistical community participant (case and control) And the extent and severity of this deficiency among newly diagnosed diabetic patients is far greater than was healthy people and the relationship between vitamin D3 deficiency and diabetes, was direct and meaningful relationship. Investigation of salivary amounts of vitamin $\mathrm{D}_{3}$ (Table 5) in the control group, briefly showed that there had been severe lack of vitamin $\mathrm{D}_{3}$ and moderate deficiency in $50.9 \%$, inadequate Vitamin D3 in $43.9 \%$ and normal levels of vitamin $\mathrm{D}_{3}$ in $5.3 \%$ of cases was reported. In case group, $7 \%$ had severe lack of vitamin $\mathrm{D}_{3}$ and $14 \%$ had moderate deficiency. There were seen, inadequate vitamin $\mathrm{D}_{3}$ in $8.36 \%$, and $42.1 \%$ normal level of vitamin $\mathrm{D}_{3}$ of cases. It is generally based on the results of salivary amounts of vitamin $\mathrm{D}_{3}$, a total of $58 \%$ of newly diagnosed diabetes patients had a deficiency of vitamin $\mathrm{D}_{3}$. 


\section{Discussion}

The measurement of higher amounts of vitamin D3 in saliva, can be attributed to release larger amounts of Protein binding to vitamin $\mathrm{D}_{3}$ (Protein-bound $25(\mathrm{OH}) \mathrm{D}_{3}$ ) in saliva (Tatsuya Higashi- 2013) and measuring $25(\mathrm{OH}) \mathrm{D}$ as a common practice, done with the commercial kit using immunoassay. Measurement of salivary $25(\mathrm{OH}) \mathrm{D}$ as a pre-hormone using unstimulated whole saliva (Collected without chewing gum) is beneficial to assess the status of vitamin $\mathrm{D}_{3}$ (Higashi et al., 2013). So, in the present study, due to higher average levels of vitamin $\mathrm{D}_{3}$ in saliva than in serum in newly diagnosed diabetic patients, can result from secrete larger amounts of protein-bound 25 $(\mathrm{OH}) \mathrm{D}_{3}$ in saliva or the result of the method of measurement or other unknown causes. Due to the nature of diabetes, vitamin $\mathrm{D}_{3}$ levels in serum or saliva, May be varying from one person to another and in various social, ethnic groups, in different geographical conditions and under different mechanisms requires extensive research for the understanding of the causes and possible mechanisms. In Agha Hosseini's study (2011) Salivary and serum levels of vitamin $\mathrm{D}_{3}$ in postmenopausal women may be maintained in the normal range and have nothing to do with the feeling of dry mouth (Agha-Hosseini, Mirzaii-Dizgah, \& Mirjalili, 2011). In healthy adults, about $85 \%$ of circulating vitamin $\mathrm{D}_{3}$, bind to vitamin $\mathrm{D}$ binding protein and there are less than $0.1 \%$ free in the plasma and plasma proteins to cross salivary membranes, are much larger and only low molecular weight compounds, be able to pass and it can be inferred that identification of higher amounts of vitamin D3 in saliva, can result from the presence of more vitamin $\mathrm{D}_{3}$-binding protein in saliva (Higashi et al., 2013).

\section{Conclusions}

In general, the deficiency of vitamin $\mathrm{D}_{3}$ in newly diagnosed diabetics, was observed also in the serum and saliva samples and compare these values together showed that saliva also Such as serum, can be a good indicator to identify the values of vitamin $\mathrm{D}_{3}$. But still serum is a better approach for this assessment and more research needs to be done on saliva. According to the results of this study, suggested that taking into consideration the limitations do the research and trying to solve them, design and conduct more studies on the measurement of vitamin D3 in the saliva. Also, if confirmed the results of this research, based on the prevalence of vitamin $\mathrm{D}_{3}$ deficiency, it is recommended that Measuring vitamin $\mathrm{D}_{3}$ routinely included Screening for type 2 diabetes. In the prevention of the progression of the internal disorders to diabetes, or in cases of newly diagnosed diabetes, Supplementation and diets rich in vitamin $\mathrm{D}_{3}$ at the start of treatment, may be prevented the incidence of many complications of diabetes in more advanced stages of disease, requires further research and more comprehensive to find the relationship between lack of vitamin $\mathrm{D}_{3}$ and the various complications of diabetes or its relation to diabetes as a risk factor. The incidence and prevalence of dry mouth in diabetic patients, can be one of the reasons for the increase vitamin $\mathrm{D}_{3}$ concentrations in the saliva. Therefore, more research is needed in this area.

\section{References}

Agha-Hosseini, F., Mirzaii-Dizgah, I., \& Mirjalili, N. (2011). Serum and stimulated saliva 25-hydroxy vitamin D in menopausal women with xerostomia. Materia Socio-Medica, 23(1), 4.

Association, A. D. (2014). Diagnosis and classification of diabetes mellitus. Diabetes care, 37(Supplement 1), S81-S90.

Atlas, I. D. (2015a). Brussels, Belgium: International Diabetes Federation; 2015.[Last accessed on 2016 Jan 07]. International Diabetes Federation.

Atlas, I. D. (2015b). International Diabetes Federation, Brussels, 2015.

Baziar, N., DJafarian, K., Shadman, Z., Qorbani, M., Khoshniat Nikoo, M., \& Razi, F. (2014). Effect of vitamin d supplementation on improving vitamin d levels and insulin resistance in vitamin $\mathrm{D}$ insufficient or defficient type2 diabetics. Iranian Journal of Diabetes and Metabolism, 13(5), 425-433.

Boucher, B. J. (1998). Inadequate vitamin D status: does it contribute to the disorders comprising syndrome 'X'? Br J Nutr, 79(4), 315-327.

Carda, C., Mosquera-Lloreda, N., Salom, L., Gomez de Ferraris, M., \& Peydró, A. (2006). Structural and functional salivary disorders in type 2 diabetic patients. Medicina Oral Patologia Oral y Cirugia Bucal, 11(4), 209.

Danescu, L. G., Levy, S., \& Levy, J. (2009). Vitamin D and diabetes mellitus. Endocrine, 35(1), 11-17.

Esteghamati, A., Meysamie, A., Khalilzadeh, O., Rashidi, A., Haghazali, M., Asgari, F., . . Abbasi, M. (2009). Third national Surveillance of Risk Factors of Non-Communicable Diseases (SuRFNCD-2007) in Iran: methods and results on prevalence of diabetes, hypertension, obesity, central obesity, and dyslipidemia. $B M C$ Public Health, 9, 167. https://doi.org/10.1186/1471-2458-9-167 
Fairney, A., \& Saphier, P. (1987). Studies on the measurement of 25 -hydroxy vitamin D in human saliva. British Journal of Nutrition, 57(01), 13-25.

Greabu, M., Battino, M., Mohora, M., Totan, A., Didilescu, A., Spinu, T., . . . Radulescu, R. (2009). Saliva-a diagnostic window to the body, both in health and in disease. J Med Life, 2(2), 124-132.

Gu, D., Reynolds, K., Duan, X., Xin, X., Chen, J., Wu, X., . . Group, I. C. (2003). Prevalence of diabetes and impaired fasting glucose in the Chinese adult population: International Collaborative Study of Cardiovascular Disease in Asia (InterASIA). Diabetologia, 46(9), 1190-1198.

Higashi, T., Hijikuro, M., Yamagata, K., \& Ogawa, S. (2013). Overestimation of salivary 25-hydroxyvitamin D 3 level when using stimulated saliva with gum-chewing. Steroids, 78(9), 884-887.

Hosseinpanah, F., Yarjanli, M., Sheikholeslami, F., Heibatollahi, M., Eskandary, P. S., \& Azizi, F. (2011). Associations between vitamin D and cardiovascular outcomes; Tehran Lipid and Glucose Study. Atherosclerosis, 218(1), 238-242.

International Diabetes Federation - Search. (2017). Retrieved from http://www.idf.org/search/site/iran.

J Boucher, B. (2011). Vitamin D insufficiency and diabetes risks. Current drug targets, 12(1), 61-87.

Krishna, A. B., Ashalatha, G., Baghirath, P. V., Kanth, A. R., \& Malathi, N. (2010). Saliva as a diagnostic bio fluid-Review. Journal of Orofacial Sciences, 2(3), 66.

Makariou, S., Liberopoulos, E. N., Elisaf, M., \& Challa, A. (2011). Novel roles of vitamin D in disease: what is new in 2011? European journal of internal medicine, 22(4), 355-362.

Mauss, D., Jarczok, M. N., Hoffmann, K., Thomas, G. N., \& Fischer, J. E. (2015). Association of vitamin d levels with type 2 diabetes in older working adults. Int J Med Sci, 12(5), 362-368.

Pittas, A. G., Lau, J., Hu, F. B., \& Dawson-Hughes, B. (2007). The role of vitamin D and calcium in type 2 diabetes. A systematic review and meta-analysis. The Journal of Clinical Endocrinology \& Metabolism, 92(6), 20172029.

Rahimi, M. A., Izadi, N., Niromand, E., Rezvanmadani, F., Najafi, F., Asarezadegan, M., \& Rafiee, E. (2016). Comparison of serum level of 25-hydroxy vitamin d in diabetic patients and healthy subjects. medical journal of mashhad university of medical sciences, 59(2), 97-105. https://doi.org/10.22038/mjms.2016.7337

Saeidinia, A., Larijani, B., Jalalinia, S., Farzadfar, F., Keshtkar, A., Rezaei, E., \& Esmaeili, I. (2013). Review the prevalence of vitamin D deficiency in the Iranian population residing in the Islamic Republic of Iran to the separation of the province ranged 2010-1990. Iranian Journal of Diabetes and Lipid Disorders, 12(6), 574584.

Scragg, R., Holdaway, I., Singh, V., Metcalf, P., Baker, J., \& Dryson, E. (1995). Serum 25-hydroxyvitamin D 3 levels decreased in impaired glucose tolerance and diabetes mellitus. Diabetes research and clinical practice, 27(3), 181-188.

talaei, a., mohamadi kelishadi, m., \& adgi, z. (2011). The evaluation of the effect of vitamin D on insulin resistance in type II diabetic patients. Arak Medical University Journal, 14(5), 79-84.

Tangpricha, V., \& Khazai, N. (2010). Vitamin D deficiency and related disorders. Medscape. 2012. Sur. Retrieved from http://emedicine.medscape.com/article/128762-overview

Zittermann, A. (2006). Vitamin D and disease prevention with special reference to cardiovascular disease. Progress in biophysics and molecular biology, 92(1), 39-48.

Zittermann, A., Schleithoff, S. S., Tenderich, G., Berthold, H. K., Körfer, R., \& Stehle, P. (2003). Low vitamin D status: a contributing factor in the pathogenesis of congestive heart failure? Journal of the American College of Cardiology, 41(1), 105-112.

\section{Copyrights}

Copyright for this article is retained by the author(s), with first publication rights granted to the journal.

This is an open-access article distributed under the terms and conditions of the Creative Commons Attribution license (http://creativecommons.org/licenses/by/4.0/). 